\title{
Using the HAZOP procedure to assess a steam boiler safety system at a university hospital located in Brazil
}

Utilização do HAZOP para avaliação da segurança de caldeiras a vapor em um hospital universitário localizado no Brasil

Marcos Lucas de Oliveira' - Universidade Federal de Santa Maria, Departamento de Engenharia de Produção e Sistemas Janis Elisa Ruppenthal² - Universidade Federal de Santa Maria, Departamento de Engenharia de Produção e Sistemas

ABSTRACT The fierce competition between organizations has stimulated the production sector to improve its production processes simultaneously with the quality of its products, which, in short, heats up the economy and presents strong challenges to government agencies and employers, especially when considering the safety of employees in their workplace. The differential of this study is stated in the application of HAZOP in the boiler sector of a hospital, in other words, , in the micro industrial area of a company that provides services In this context, this paper aims to identify the risks present in the fire-tube boilers of the University Hospital of Santa Maria, RS. The method used follows the application practices of the HAZOP tool. Therefore, on this basis, we proceeded with bibliographic analysis, methodologies, references, on-site visits at the university hospital, and studies of investments made in steam generators. Due to this study, it was possible to show that the industry under study has no operation and maintenance default for the boiler, resulting in a high possibility of failure in the system as a whole and, in the case of an explosion, catastrophic consequences.

Keywords: Risks. Safety. HAZOP. Boiler. Hospital.

RESUMO A concorrência entre as organizações tem estimulado o setor produtivo a melhorar seus processos de produção concomitantemente com a qualidade de seus produtos, o que, em suma, aquece a economia e traz grandes desafios para as agências governamentais e os empregadores, especialmente quando se considera a segurança dos funcionários no local de trabalho. O diferencial deste estudo é expresso na aplicação do HAZOP no setor de caldeiras de um hospital, ou seja, na área micro industrial de uma empresa de prestação de serviços. Neste contexto, este trabalho tem como objetivo identificar os riscos presentes no setor das caldeiras do Hospital Universitário de Santa Maria, RS. O método utilizado segue as práticas de aplicação da ferramenta HAZOP. Assim, a composição do estudo ocorreu através de uma análise bibliográfica, metodologias, referências, visitas in loco no hospital escola e estudos sobre geradores de vapor. Através desse estudo, foi possível evidenciar que o setor das caldeiras não tem nenhum procedimento padrão de operação e manutenção da caldeira, resultando em uma alta possibilidade de falha no sistema como um todo e, em caso de explosão, consequências catastróficas.

Palavras-chave: Riscos. Segurança. HAZOP. Caldeira. Hospital. 


\section{INTRODUCTION}

Technological and social advances has improved the manufacturing processes and has led to a sharp industrial growth. These changes resulted in larger and more complex industrial plants, involving certain accident risks that need to be identified, controlled and minimized (FUENTES-BARGUES et al., 2016).

According to the International Labor Organization (INTERNATIONAL LABOUR ORGANIZATION, 2012), 2.4 million people die every year as a result of unsafe or unhealthy workplace conditions. Every year there are more than 330 million work-related accidents worldwide. This causes an estimate loss of 4 per cent of global Gross Domestic Product (GDP), and this value could be added up to 10 per cent of national GDP in some countries. Therefore, prevention is becoming an important subject for governments, economic leaders, managers and stakeholders.

In addition, there is an increasing indication that providing a healthy and safe working environment has the potential to enhance labor productivity and, consequently, increase business profits (HESAPRO, 2013; BUHAI, COTTINI, WESTERGAARD-NIELSEN, 2016; IRIMIE et al., 2015). The improvement of the Occupation Security and Health $(\mathrm{OSH})$ sector results on a reduction of risks, leading to the preservation of health, improving the operating performance of employees and enhancing the company's image (EUROPEAN AGENCY FOR SAFETY AND HEALTH AT WORK, 2000; EUROPEAN AGENCY FOR SAFETY AND HEALTH AT WORK 2007).

In this context, the term risk can be characterized as the effect of uncertainty on determined objectives. Thus, risk analysis involves identification, recognition, evaluation and gradation of risks followed by controls in order to mitigate the probability of the causes occurrence and risk effects (INTERNATIONAL STANDARD ORGANIZATION, 2009). Therefore, identifying risks is fundamental for ensuring the safe design and operation of a system processes and facilities (DUNJÓ et al., 2010).

The decision by the appropriate risk assessment technique is will depend on factors such as the complexity of the problem, the amount of information available, the need for quantitative data, and available resources. Overall, the 
Hazards and Operability Study (HAZOP) is probably the most commonly used risk analysis and hazard study in industry (TYLER, 2012; FUENTES-BARGUES et al., 2016). Thus, as a means to identify the current situation of the boiler sector of the university hospital, as to the operation risks, chose the hazop because it is a technique that helps the managers to identify the existing risks in the current situation of the company (LEE; CHANG, 2014), that corroborates with purpose of this study.

HAZOP is a systematic procedure to identify causes and consequences of process deviations from normal behavior, and therefore eliminate or mitigate hazards (SRINIVASAN; VENKATASUBRAMANIAN, 1998). In the risk identification process, a multidisciplinary team of experts commonly performs this analysis during brainstorming sessions (GUO; KANG, 2015). The method provides an identification of accidental events and operability problems by using logical sequences of cause-deviation-consequence of process parameters (GIARDINA; MORALE, 2015).

In view of this, the present article proposes to identify the hazards present in the operating phase of flame tube boilers of the University Hospital of Santa Maria (HUSM) with the use of Hazards and Operability Studies (HAZOP) tools. As a problem issue of the study we have: is the non-use of standard operating procedures in steam boilers provide risks for the unit operators and the users of the hospital service? The justification for this work is based on the identification of improvements in controlling the process of HUSM's boiler's sector, seeking for the safety and physical integrity of employees.

In this way, the theoretical contribution of the present study is the application of the HAZOP risk assessment technique, in a low scale, in the boiler sector of a hospital. Wherefore, the procedures for applying this study can be used as a basis for understanding the application of the technique in the hospital sector. However, this study it cannot be generalized to other hospitals, since there is dependence on the characteristics of the operation, which must be analyzed in loco. 


\section{DEFINITIONS}

\subsection{Study of risks}

Hazard determination and risk assessment studies are an important element in occupational health and safety in industrial process and industrial facilities. The term risk has been defined as the combination of the severity and the occurrence probability of a determined hazardous event (BRITISH STANDARDS INSTITUTION, 2007; GUL; GUNERI, 2016). In other words, the term "risk" can be characterized as the effect of uncertainty on determined objectives (INTERNATIONAL STANDARD ORGANIZATION, 2009).

The process of risk management starts primarily with the identification and analysis of risks of accidental losses that threaten the organization and, then, evolve into a continuous and systematic process (DE CICCO; FANTAZZINI, 2003; MORAES, 2010). Thus, the development of a risk analysis operation program involves identification, recognition, evaluation and gradation of risks followed by controls in order to mitigate the probability of the causes occurrence and risk effects.

In this context, risk management is the systematic practice of selecting necessary actions to minimize or avoid the materialization of potential causes that can lead to the occurrence of accidents. Therefore, risks can be minimized into tolerable levels set by the company or the process under analysis. Risk analysis methods have the goal to assess one or several risk related quality attributes of systems, components or even processes with respect to causes and consequences (DE CICCO; FANTAZZINI, 2003; FREIBOTT, 2013; ZENDEL el al., 2016). All risk analysis methods define systematic processes for identifying potential risks. 


\subsection{Maintenance}

Maintenance concerns the combination of technical, administrative and managerial actions during the life cycle of an item or equipment intended to retain it in, or restore it to, a specific condition (DHILLON, 2006; COMITÉ EUROPÉEN DE NORMALISATION, 2010; GOMES, 2016). Industrial systems are periodically subject to deterioration in function of its use and life cycle. Thus, the insertion of a maintenance policy becomes essential in organizations to mitigate problems (FREIBOTT, 2013).

A correct and regular maintenance program is necessary to keep both machines and work environment safe and reliable. Although, maintenance itself has to be executed in a safe way (EUROPEAN AGENCY FOR SAFETY AND HEALTH AT WORK, 2010). The application of maintenance techniques combined with quality and safety assessment tools, account as very effective instruments to increase companies productivity, safety and quality (MANZINI et al., 2010).

Therefore, maintenance could be classified as corrective, preventive, predictive and detective. Normally, the corrective maintenance is an unplanned maintenance action that requires urgent attention where remedial measures take place after the fault detection. In its turn, the preventive maintenance actions are performed to reduce failure or drop in performance according to a planning based on established regular periods. Detection and correction of incipient failures are performed before their development into major failures or before their occurrence (MANZINI et al., 2010; SUGANTHI; ANAND, 2011).

The predictive maintenance looks for malfunctions evidences and once it is found the appropriate maintenance is carried out. Similarly, the detective maintenance is done for equipment that are not in constant use. The periodic inspection is carried out to certify that systems will work properly when requested (SUGANTHI; ANAND, 2011). 


\subsection{Hazards and Operability Study (HAZOP)}

A Hazard and Operability study (HAZOP) is a systematic technique that aims at the identification of hazards. It was originally created for the chemical industry (KOPCZYŃSKA; NAWROCKI, 2016). That technique is widely used for systems processing and handling hazardous material. Therewithal is a systematic technique for identifying potential hazards and operability problems. HAZOP involves a systematic examination of design documents that describe the installation or the facility under investigation (LEE; CHANG, 2014).

For the Chen et al. (2016), HAZOP is a structural analysis used for identifying design defects, process hazards and operating risk. The analysis is practiced by serial conferences to analyze process diagrams and operation procedures. This method assumes the process deviations from the planned operations based on the use of guidewords, each part of the design is questioned with the use of combinations of guide words: primary keywords (attributes).

The first step in a HAZOP is to identify the essential components of the system to be analyzed, the parameters for each component, which define its behavior, have to be identified. During the analysis, the analysis group consisting of the professionals systematically studies every single part (i.e. the analysis node) of the system in a prescribed manner (CHEN et al., 2016; AHN; CHANG, 2016; FUENTES-BARGUES et al., 2016). The method main goal is identified hazards that may affect the safety and operability of a system at progressive phases. This method assumes the process deviations from the planned operations based on the use of guidewords (AHN; CHANG, 2016; FUENTES-BARGUES et al., 2016).

In the analysis process, a multidisciplinary team of experts and operators should examine the facility or the mechanism plant. All conceivable deviations far from design intentions in the plant should be identified and all the possible abnormal causes and the adverse consequences of these deviations should be determined (WANG, GAO; WANG, 2012). 
For this purpose, the HAZOP team members try, in a brainstorming session, to imagine in which ways hazards and operating problems might occur. To cover all the potential problems, the team apply the guide words to process parameters at different locations, called nodes (BAYBUTT, 2015).

The evaluation of risks is estimated by numerically multiplying the frequency and consequence of the event (AHN; CHANG, 2016). Therefore, the HAZOP report results generally involves deviation, causes, possible consequences, existing safeguards, and corresponding recommendations (JANG; GUO, 2016).

\subsection{Boilers}

The Brazilian Regulatory Standards on Health and Safety at Work define steam boiler as an equipment used to generate and accumulate steam at pressures higher than atmospheric pressure, using any source of heat (BRASIL, 2014). The risk of accident of such equipment tends to increase as the material's allowable stress and wall thickness are reduced.

Steam boilers are classified into three different categories, as show in Table 1 . The boilers of category "A" provide the highest risks, while the ones in category "B" represent the lowest risks (BRASIL, 2014; JANG; GUO, 2016). In general, boilers can be classified as fire-tube and water-tube. The flame tube boilers, subject of this case study, are characterized by internal circulation of the combustion gases in operation with liquid or gaseous fuels.

Table 1 - Steam boiler categories.

\begin{tabular}{|c|c|c|c|}
\hline \multirow{2}{*}{ Class } & \multicolumn{2}{|c|}{ Operating pressure } & \multirow{2}{*}{$\begin{array}{l}\text { Inner Volume } \\
\text { (Liter) }\end{array}$} \\
\hline & $\mathrm{kPa}$ & $\mathrm{Kgf} / \mathrm{cm}^{2}$ & \\
\hline A & $\geq 1960$ & $\geq 19.98$ & - \\
\hline B & $\leq 588$ & $\leq 5.99$ & $\geq 100$ \\
\hline c & \multicolumn{3}{|c|}{ Out of previous parameters } \\
\hline
\end{tabular}

Source: (Brasil, 2014). 
The functionality of fire-tube boilers is restricted to the production of saturated steam. The work pressures are not high and possess limitations regarding the thickness of the outer wall of the side, once that the greater the thickness, the higher the pressure.

The fire-tube boiler operation is characterized as simple, once it has few equipment to monitor the operation. However, this factor favors the occurrence of accidents. According to Ruppenthal (2013), this type of boiler leads the accident statistics in the world, since it is common the presence of negligence in its operating processes and maintenance.

\section{METHODOLOGICAL PROCEDURES}

\subsection{Case study}

It was performed a case study in which was possible to identify the risk factors present in the flame tube boiler's operating phase, focusing on the main risks noticed in workplaces. The application was conducted in a federal organization of the hospital sector (HUSM), located in Santa Maria, Rio Grande do Sul, Brazil.

The University Hospital of Santa Maria (HUSM), founded in 1970, is recognized as a health reference for the central region of the state. The institution works as a school hospital in the Federal University of Santa Maria (UFSM) with attention focused in developing education, research and public health assistance. The hospital serves a monthly average of 11.3 thousand specialized consultations, 4.6 thousand emergency consultations and execute approximately 760 thousand medical examinations and 10.8 thousand hospitalizations per year (HUSM, 2016).

The HUSM possess two flame tube boilers, both manufactured in 1971. The boiler in analysis is a horizontal flame tube $\mathrm{H}-3 \mathrm{~N}$ model, category $\mathrm{B}$, with production capacity of 3,300 kg.v/h, maximum allowable working pressure (MAWP) or permissible (MPWP) of $150 \mathrm{Lbs} / \mathrm{pol}^{2}\left(10.55 \mathrm{kgf} / \mathrm{cm}^{2}\right)$ and hydrostatic pressure of $225 \mathrm{Lbs} / \mathrm{pol}^{2}\left(15.82 \mathrm{kgf} / \mathrm{cm}^{2}\right)$ with vaporization area up to $100 \mathrm{~m}^{2}$. 
The boilers sector is responsible for supplying steam to: laundry, autoclaves, kitchen, showers and more. This sector has five boiler operators that alternate with each other in a work schedule scheme that consists of two operators per scale. The shift begins at 6 a.m., and the system shutdown occurs at 10 p.m.

Initially, it was identified a lack of standard procedure to the boiler's operation once the five operators use different procedures to operate the hospital's flame tube boiler. Accordingly, for apply the methods proposed in the study it was necessary to map the process for the steps to be focused on the boiler's risk study in order to establish an operation pattern.

For the creation of these flowcharts it was used the brainstorming technique. In order to apply it, four standard procedures were established: (i) team definition; (ii) definition of the central focus; (iii) generation of concept; (iv) selection of concept. This stage of the study required two on-site visits to the hospital boiler unit for the procedure of the meetings, and in each, the average duration was one hour.

From this, the action team was initially built in order to solve the problem, which consisted of the boiler operators, the mechanical engineer, the safety engineer and the researchers of that study. For the second stage of Brainstorming was defined as focus centric the establishment of a standard procedure for turning the boilers on and off. Thus, for the third stage, the idea generation was applied.In the last step, the safety engineer along with the researchers discussed the main points of the standard procedure that was established.

Slack, Chambers and Johnston (2009), point out that the application of the Brainstorming technique is a disciplined way of generating new ideas from group discussion. It was also necessary to set one stage of the operating process to the study application. For use, analysis and identification of the HAZOP method, spreadsheets with color scales for mapping risk and weighting scale were structured, as shown in Figure 1. 
Figure 1 - Matrix of risk magnitude.

\begin{tabular}{|c|c|c|c|c|c|c|}
\hline & GRAVITY & \multicolumn{5}{|c|}{ PROBABILITY } \\
\hline & \multirow{3}{*}{ CATEGORY } & 1 & 2 & 3 & 4 & 5 \\
\hline & & Improbable & Remote & Occasional & Probable & Frequent \\
\hline & & $\begin{array}{l}\text { Once every } 100 \\
\text { years or more }\end{array}$ & $\begin{array}{c}\text { Once every } \\
10 \text { years }\end{array}$ & $\begin{array}{l}\text { Once } \\
\text { a year }\end{array}$ & $\begin{array}{c}\text { Until five times } \\
\text { a year }\end{array}$ & $\begin{array}{c}\text { More than five } \\
\text { times a year }\end{array}$ \\
\hline 5 & Catastrofic (C) & 5 & 10 & 15 & 20 & 25 \\
\hline 4 & Critical (CR) & 4 & 8 & 12 & 16 & 20 \\
\hline 3 & Moderate (MO) & 3 & 6 & 9 & 12 & 15 \\
\hline 2 & Marginal (MA) & 2 & 4 & 6 & 8 & 10 \\
\hline \multirow[t]{6}{*}{1} & Negligible (N) & 1 & 2 & 3 & 4 & 5 \\
\hline & & \multicolumn{5}{|c|}{ RISK MAGNITUDE } \\
\hline & & Magnitude & \multicolumn{4}{|c|}{ Probability $x$ Gravity } \\
\hline & & Severe & \multicolumn{4}{|c|}{10 to 25} \\
\hline & & Significant & \multicolumn{4}{|c|}{4 to 9} \\
\hline & & Tolerable & \multicolumn{4}{|c|}{1 to 3} \\
\hline
\end{tabular}

Source: Authors.

Therefore, HAZOP application was performed in the boiler's water and pressure (steam) flows. For the application of HAZOP, two Knots of the flame tube boiler's system were considered. The first one was located in the boiler's water supply and the second was situated in the steam power of the pressure vessel.

\section{RESULTS}

HAZOP is a qualitative analysis technique developed to examine the process lines, identifying hazards and preventing problems. In this paper, its analysis was performed through words that guide the reasoning of multidisciplinary study groups for identifying operating discontinuities. Its application was through three basic procedures: (i) identification of the "Connections", which are the probable critical points in the system; (ii) determining the guide words able to cover the possible deviations of the evaluated system; and (iii) assessment of deviations and proposition of mitigation alternatives.

In this work, as a limiting factor, was analyzed two steps of the boiler operation, water flow and pressure. Both processes have a major impact on boiler operation, in this case. Therefore, the methodology include both cause and consequence. The application of HAZOP for the first Knot is presented in Figure 2, while Figure 3 shows the application for the second Knot. 


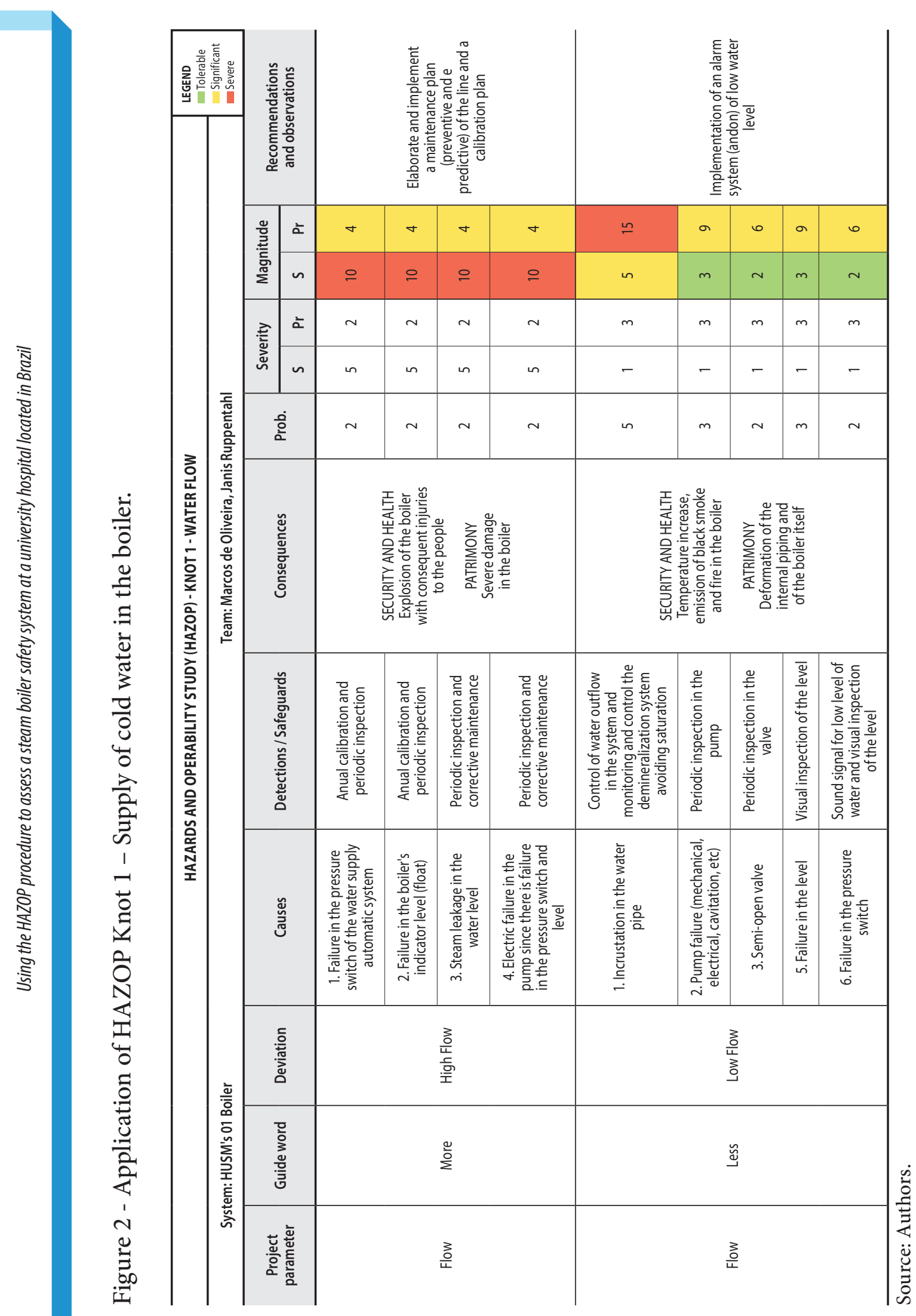

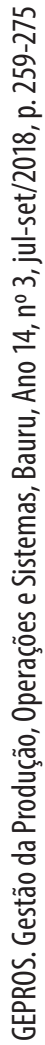



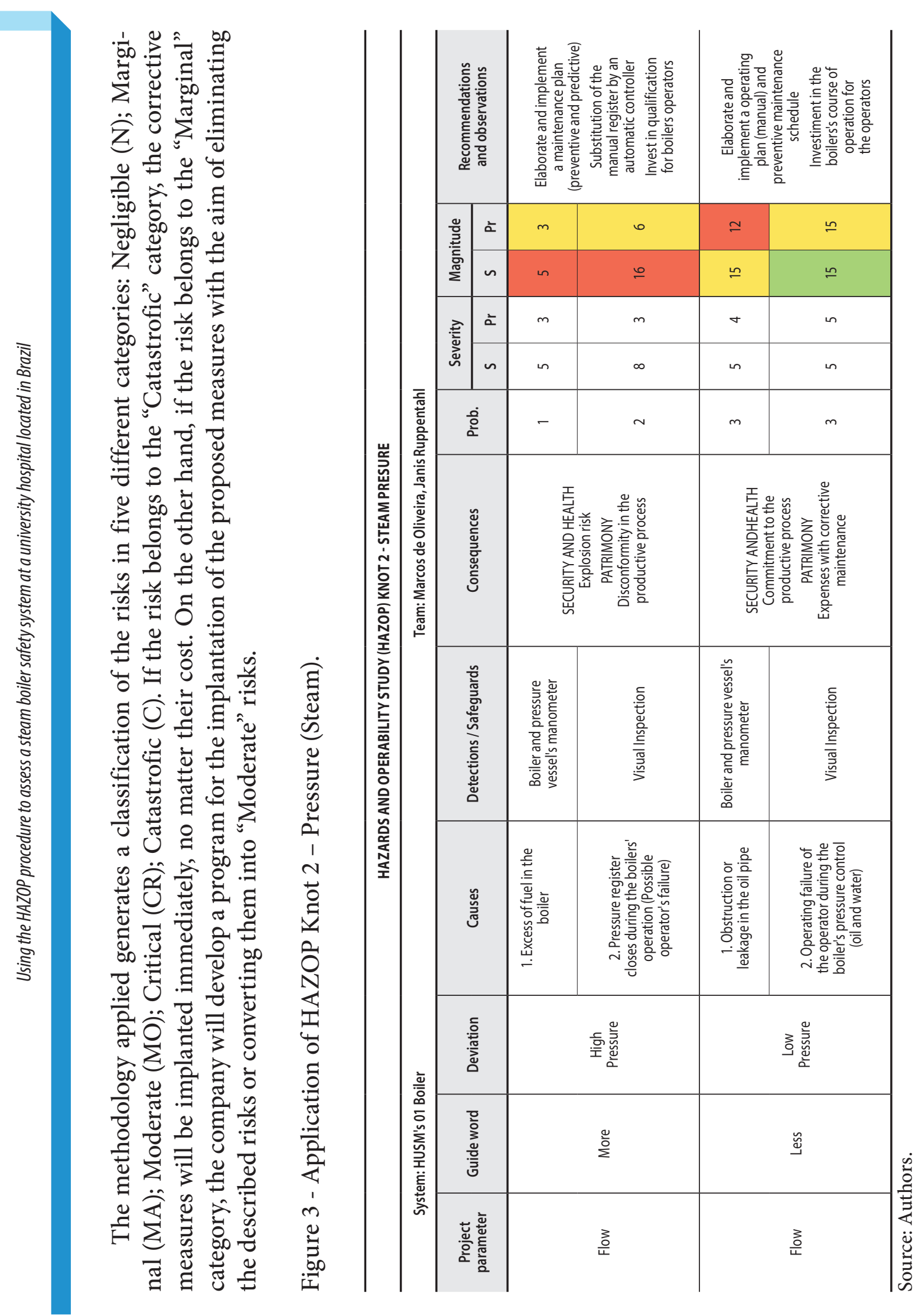

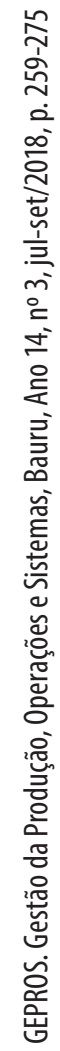


The HAZOP application pointed critical points of the system. For the first Knot, it was evident that the identified deviation concerns the low water flow (guide word: less). And for the second Knot, pressure (steam), the deviation is linked to the pressure of low steam (guide word: less) of steam pressure. Therefore, the corrective actions are: (i) implementation of a operating manual for the boiler; (ii) piping's preventive maintenance; (iii) operators' training; and (iv) implementation of an alarm (andon) system for low water level.

\section{CONCLUSION}

The use of HAZOP methodologies for the case study of the University Hospital of Santa Maria's flame tube boiler resulted in the identification the risks of system failure as a whole through the security processes currently existent in the boiler sector. Thus, it was shown in this work, before the application of the methods and through the study of the scientific literature, that the risks are likely to characteristics change in function of the organization performance environment and its operating characteristics. Therefore, the risks emerge from new corporate structures, per lack of equipment maintenance, and per technologies change without previous study of its impacts.

The limitations of this study has been the time and the sample size, which were limited because the hospital demanded the preliminary assessment of the research ethics committee. This process took about four months to be approved. In addition, the results found in this study can not be generalized, since the applied technique evaluates the existing condition of the unit under analysis. In other words, the results may vary according to the characteristics of the application place and the standard procedures adopted in the unit which is being analyzed.

However, it may be concluded by the application that the sector under study has no operating and maintenance default of the boiler which in short results in a high possibility of failure in the system as a whole and catastrophic consequences in case come an explosion. At the same time, it was observed that the use of methods helps in understanding and identifying critical points as well as in proposing corrective measures or mitigation/elimination of faults. For future work it is suggested an extension of the application of the HAZOP tool in a flamedubular boiler, which has similar characteristics to that presented in this study, in order to identify all possible flaws in the operation of the boilers. 


\section{REFERENCES}

AHN J.; CHANG, D. Fuzzy-based HAZOP study for process industry, Journal of Hazardous Materials, v. 317, p. 303-311, 2016.

BAYBUTT, P. A critique of the hazard and operability (HAZOP) study. Journal of Loss Prevention in the Process Industries, v. 33, p. 52-58, 2015.

BRASIL. Ministério do Trabalho e Emprego, NR 13 - Caldeiras e Vasos Sob Pressão, Brasília: Ministério do Trabalho e Emprego. (2014). Retrieved November 20, 2016. Disponível em: <http://acesso.mte.gov.br/data/files/ FF80808147596147014764A4E1D14497/NR-13\%20(Atualizada\%202014).pdf>. Acesso em: $10 \mathrm{dez} 2016$.

BRITISH STANDARDS INSTITUTION. Occupation Health and Safety Assessment Service (OHSAS) Project Group. OHSAS 18001:2007 Occupational health and safety management systems, Requirements, 2007.

BUHAI, I.; COTTINI, E.; WESTERGAARD-NIELSEN, N. How productive is workplace hand safety? The Scandinavian Journal of Economics, v. 119, n. 4, p. 1086-1104, 2016.

CHEN J.; LIU, X.; JING S.; XIONG G.; SHANG X.; CHENG C. A Process Simulation-Based Quantitative HAZOP Analysis Method. IEEE Transactions on Reliability, DOI: 10.1109/SOLI.2016.7551694, p. 239-244, 2016.

COMITÉ EUROPÉEN DE NORMALISATION. EN 13306:2001. Maintenance terminology. Geneva, 2011.

DE CICCO, F.; FANTAZZINI, M. Tecnologias consagradas de gestão de riscos: riscos e probabilidades. Série Risk Management, São Paulo, 2003.

DHILLON, B. Maintainability. maintenance and reliability for engineers. New York, 2006.

DUNJÓ, J.; FTHENAKIS, V.; VÍLCHEZ, J.; ARNALDOS, J. Hazard and operability (HAZOP) analysis: A literature review. Journal of Hazardous Materials, v. 173, p. 19-32, 2010. 
EUROPEAN AGENCY FOR SAFETY AND HEALTH AT WORK. Occupational safety and health in marketing and procurement. Luxembourg: Office for Official Publications of the European Communities, 2000.

EUROPEAN AGENCY FOR SAFETY AND HEALTH AT WORK. The business benefits of good occupational safety and health, Belgium, 2007.

EUROPEAN AGENCY FOR SAFETY AND HEALTH AT WORK. Mainstreaming OSH into business management, Luxembourg, 2010.

FREIBOTT, B. Sustentainable safety management: incident management as a cornerstone for a successful safety culture, Safety and Security Engineering V. WIT Press, p. 257-270, 2013.

FUENTES-BARGUES, J.; GONZÁLES-GAYA, C.; GONZÁLES-CRUZ, M.; CABRELLES-RAMÍREZ, V. Risk assessment of a compund feed process based on Hazop analysis and linguistic terms. Journal of Loss Prevention in the Process Industries, v. 44, p. 44-52, 2016.

GIARDINA, M.; MORALE, M. Safety study of an LNG regasification plant using an FMECA and HAZOP integrated methodology. Journal of Loss Prevention in the Process Industries, v. 35, p. 35-45, 2015.

GOMES, G. R. S. Identification of optimal inspection interval via delay-time concept. GEPROS. Gestão da Produção, Operações e Sistemas, v. 11, n. 2, p. 187-202, 2016.

GUL, M.; GUNERI, A. A fuzzy multi criteria risk assessment based on decision matrix technique: A case study for aluminum industry. Journal of Loss Prevention in the Process Industries, v. 40, p. 89-100, 2016.

GUO, L.; KANG, J. An extended HAZOP analysis approach with dynamic fault tree. Journal of Loss Prevention in the Process Industries, v. 38, p. 224-232, 2015.

HESAPRO. The link between productivity and health and safety at work, Background research: EU Comission under Lifelong Programme, 2013. 
HUSM. Nossa história. Retrieved September 10, 2016. Disponível em: <http:// www.ebserh.gov.br/web/husm-ufsm/informacoes/institucional/nossa-historia>. Acesso em: 10 dez 2016.

INTERNATIONAL LABOUR ORGANIZATION (ILO). Improvement of national reporting, data collection and analysis of occupation accidents and diseases, Geneva, 2012.

INTERNATIONAL STANDARD ORGANIZATION (ISO). ISO 31.000:2009 Risk management. Principle and guidelines on implementation, São Paulo, 2009.

IRIMIE, S.; MUNTEANU, R.; GHICAJANU, M.; MARICA, L. Aspects of the safety and health at the workplace, Procedia Economics and Finance, v. 23, n. 3, p. 152-160, 2015.

JANG, J.; GUO, L. HAZOP analysis based on sensitivity evaluation. Safety Science, v. 88, p. 26-32, 2016.

KOPCZYŃSKA S.; NAWROCKI J. HAZOP-based approach to pattern identification for non-functional requirements, 5th International Workshop on Requirements Patterns, RePa 2015 - Proceedings, p. 39-46, 2016.

LEE, S.; CHANG, D. Safety Systems Design of VOC Recovery Process Based on HAZOP and LOPA, Process Safety Progress, v. 33, p. 339-344, 2014.

MANZINI, R.; REGATTIERI, A.; HOANG, P.; FERRARI, E. Maintenance for industrial systems, London, 2010.

MORAES, G. Sistemas de gestão de riscos: Princípios e diretrizes - ISO 31000:2009 comentada e ilustrada, Rio de Janeiro, 2010.

RUPPENTHAL J. Gerenciamento de riscos - Santa Maria: UFSM, Colégio técnico Industrial de Santa Maria. Rede e-Tec Brasil, Santa Maria, 2013. Disponível em: <https://s3.amazonaws.com/academia.edu.documents/44960581/ gerenciamento_riscos.pdf?AWSAccessKeyId=AKIAIWOWYYGZ2Y53UL3A \&Expires $=1533578018 \&$ Signature $=$ JaY6n6T1kJzaVriG413\%2Bv2AcEPY\%3D\& response-content-disposition $=$ inline $\% 3 \mathrm{~B} \% 20$ filename $\% 3 \mathrm{DGerenciamento}$ de_Riscos_2013_Santa_Maria.pdf $>$. Acesso em: 10 dez 2016. 
SRINIVASAN, R.; VENKATASUBRAMANIAN, V. Automating HAZOP analysis of batch chemical plants: Part I. The knowledge representation framework. Computers and chemicals engineering, v. 22, n. 9, p. 1345-1355, 1998.

SLACK, N.; CHAMBERS, S.; JOHNSTON, J. Administração da produção. São Paulo: Atlas, 3ed. 2009.

SUGANTHI, L.; ANAND, A. Total Quality Management, New Dehli, 2011.

TYLER, B. HAZOP study training from the 1970s to today. Process Safety and Environmental Protection, v. 90, p. 419-423, 2012.

WANG, F.; GAO J.; WANG, H. A new intelligent assistant system for HAZOP analysis of complex process plant. Journal of Loss Prevention in the Process Industries, v. 25, p. 636-642, 2012.

ZENDEL, O.; MURSCHITZ, M.; HUMENBERGER, M.; HERZNER, W. CV-HAZOP: Introducing test data validation for computer vision. Proceedings of the IEEE International Conference on Computer Vision, v. 11-18, p. 20662074. http://doi.org/10.1109/ICCV.2015.239, 2016. 